\title{
Front Matter: Volume 11374
}

, "Front Matter: Volume 11374," Proc. SPIE 11374, Bioinspiration, Biomimetics, and Bioreplication X, 1137401 (21 May 2020); doi: $10.1117 / 12.2572621$

SPIE. Event: SPIE Smart Structures + Nondestructive Evaluation, 2020, Online Only 


\section{PROCEEDINGS OF SPIE}

\section{Bioinspiration, Biomimetics, and Bioreplication $X$}

Mato Knez

Akhlesh Lakhtakia

Raúl J. Martín-Palma

Editors

27 April - 8 May 2020

Online Only, United States

Sponsored by

SPIE

Cooperating Organizations

Jet Propulsion Laboratory (United States)

Published by

SPIE 
The papers in this volume were part of the technical conference cited on the cover and title page. Papers were selected and subject to review by the editors and conference program committee. Some conference presentations may not be available for publication. Additional papers and presentation recordings may be available online in the SPIE Digital Library at SPIEDigitalLibrary.org.

The papers reflect the work and thoughts of the authors and are published herein as submitted. The publisher is not responsible for the validity of the information or for any outcomes resulting from reliance thereon.

Please use the following format to cite material from these proceedings:

Author(s), "Title of Paper," in Bioinspiration, Biomimetics, and Bioreplication X, edited by Mato Knez, Akhlesh Lakhtakia, Raúl J. Martín-Palma, Proceedings of SPIE Vol. 11374 (SPIE, Bellingham, WA, 2020) Seven-digit Article CID Number.

ISSN: 0277-786X

ISSN: 1996-756X (electronic)

ISBN: 9781510635258

ISBN: 9781510635265 (electronic)

Published by

SPIE

P.O. Box 10, Bellingham, Washington 98227-0010 USA

Telephone +1 3606763290 (Pacific Time) · Fax +1 3606471445

SPIE.org

Copyright (C) 2020, Society of Photo-Optical Instrumentation Engineers.

Copying of material in this book for internal or personal use, or for the internal or personal use of specific clients, beyond the fair use provisions granted by the U.S. Copyright Law is authorized by SPIE subject to payment of copying fees. The Transactional Reporting Service base fee for this volume is $\$ 21.00$ per article (or portion thereof), which should be paid directly to the Copyright Clearance Center (CCC), 222 Rosewood Drive, Danvers, MA 01923. Payment may also be made electronically through CCC Online at copyright.com. Other copying for republication, resale, advertising or promotion, or any form of systematic or multiple reproduction of any material in this book is prohibited except with permission in writing from the publisher. The CCC fee code is 0277$786 \mathrm{X} / 20 / \$ 18.00$.

Printed in the United States of America by Curran Associates, Inc., under license from SPIE.

Publication of record for individual papers is online in the SPIE Digital Library.

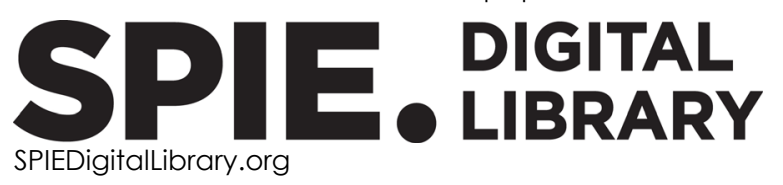

Paper Numbering: Proceedings of SPIE follow an e-First publication model. A unique citation identifier (CID) number is assigned to each article at the time of publication. Utilization of CIDs allows articles to be fully citable as soon as they are published online, and connects the same identifier to all online and print versions of the publication. SPIE uses a seven-digit CID article numbering system structured as follows:

- The first five digits correspond to the SPIE volume number.

- The last two digits indicate publication order within the volume using a Base 36 numbering system employing both numerals and letters. These two-number sets start with 00, 01, 02, 03, 04, $05,06,07,08,09,0 A, 0 B \ldots$ OZ, followed by 10-1Z, 20-2Z, etc. The CID Number appears on each page of the manuscript. 


\section{Contents}

\section{COLORS AND VISUALIZATION}

1137406 Optical analysis on the Morpho butterfly's in-plane randomness using three-dimensional FDTD simulations [11374-5]

1137407 Towards three-dimensional point cloud reconstruction of fish swimming [11374-6]

\section{BIOINSPIRED SOLUTIONS AND DESIGN}

11374 OA The ultimate bio-inspiration: how to build a self-replicating machine to colonize the Moon [11374-9]

$11374 \mathrm{OB} \quad$ A coupled CFD and multibody analysis of the hydrodynamics of batoid fish [11374-10]

11374 OC Invasive alien species respond to biologically-inspired robotic predators [1 1374-11]

11374 OE Biologically inspired design for environment [11374-13]

$113740 G$ A flexible spiny structure featuring two anchoring points for enhancing the mobility of wallclimbing robots on rough surfaces [11374-15]

\section{SOFT ROBOTICS}

$113740 \mathrm{~J}$ The effect of resistive forces in variable recruitment fluidic artificial muscle bundles: a configuration study [11374-19]

\section{FLIGHT AND NAVIGATION}

11374 OK Bio inspired visual navigation over water [11374-20]

$11374 \mathrm{OL}$ The beam modelling of the hawkmoth wing structure [11374-21]

\section{MATERIALS II}

11374 OS Computational and experimental investigation of bio-inspired 3D printed prototypes [1 1374-30] 


\section{POSTER SESSION}

11374 OU Experimental verification of motion pattern generation for peristaltic mobile robot using numerical optimization method [1 1374-32]

$113740 X \quad$ Design of a biomimetic robot inspired to the cownose ray [11374-35]

11374 OY Design of a soft pneumatic robot inspired to plant roots' growth [11374-36]

iv 